\title{
Jakub Potulski
}

\section{„Wyobrażenia \\ geopolityczne" \\ jako przedmiot badań współczesnej \\ geografii politycznej}

\section{Wprowadzenie}

Polityka jako działalność społeczna człowieka jest silnie osadzona w przestrzeni. Granice, które oddzielaja poszczególne społeczności, państwa posiadajace swoje terytoria, mapa polityczna świata - sa to wszystko wytwory ludzkiej działalności o charakterze politycznym, które obiektywizują się w przestrzeni geograficznej. Przestrzeń ma ogromne znaczenie dla życia społecznego zbiorowości ludzkich i często jest głównym źródłem konfliktów grupowych. Jednostki i grupy społeczne dążą ustanowienia oraz utrzymania obszarów, do których dostęp dla innych będzie ograniczony. Jak pisał Jean Gottmann, olbrzymia liczba słów, a także wiele atramentu i krwi zostało rozlane $z$ powodu sporów terytorialnych ${ }^{1}$.

Jakub Potulski (ORCID 0000-0003-4139-5590) - doktor habilitowany, profesor Uniwersytetu Gdańskiego, pracuje w Instytucie Politologii tej uczelni, w Zakładzie Systemów Politycznych. Zainteresowania badawcze: socjologia polityki, geografi a polityczna, rosjoznawstwo. Autor dziesięciu samodzielnych monografi i oraz ponad stu artykułów naukowych.

J. Gottmann, The Significance of Territory, University of Virginia Press, Charlottesville 1973, s. ix. 
Ludzka terytorialność - czyli procesy i mechanizmy, za pomoca których grupy społeczne ustanawiaja, utrzymuja i bronia swojego terytorium - zawsze budziła zainteresowanie badaczy zafascynowanych sposobami rozgrywania wzajemnie sprzecznych roszczeń dotyczacych kontroli i zarządzania przestrzenią. Nauka od zarania swojego istnienia zajmowała się geograficznymi uwarunkowaniami wielorakiej działalności człowieka, społeczeństw i państw. Ciekawość wobec własnego otoczenia przyczyniała się do zdobywania wiedzy na jego temat oraz do ukształtowania się w świadomości człowieka nieformalnej wiedzy geograficznej, która dostarczała względnie uporząlkowanego i spójnego obrazu otoczenia. Ta początkowo nieformalna wiedza stopniowo zaczęła się przekształcać w wiedzę formalna, o walorach uniwersalnych. Uzyskiwała stopniowo autonomię i w dobie tworzenia się nowoczesnej nauki zaczęto ją określać jako „geografię". Wiedzę na temat przestrzennych uwarunkowań zjawisk politycznych zaczęto nazywać "geografią polityczną". To właśnie w ramach geografii politycznej zaczęła się także rozwijać geopolityka.

Historia rozwoju geopolityki sama w sobie jest interesujacym obszarem badań. Geografia polityczna - jako dyscyplina badająca związki zachodzące między człowiekiem i jego aktywnością społeczna o charakterze politycznym a przestrzenia - zawsze była dyscyplina dynamiczną i odzwierciedleniem czasów, w których powstawały jej teorie ${ }^{2}$. Przemieszanie się nauki i ideologii szczególnie widoczne stało się w przypadku geopolityki, która jako specyficzny obszar badań rozwijała się przede wszystkim na przełomie XIX i XX wieku, a obecnie przeżywa renesans popularności. Renesans ten, przynajmniej w środowisku akademickim, jest zwiąany $z$ zaadoptowaniem do badań z zakresu geografii politycznej nowych sposobów analizy i nowego spojrzenia na relacje człowiek-przestrzeń. We współczesnej geografii politycznej - nawiąujacc do teorii krytycznej, filozofii poststrukturalistycznej i geografii radykalnej - zaczęto podkreślać, że geopolityczne „teorie” nie sa obiektywna prawdą o walorach na-

2 Zob. M. Blacksell, Geografia polityczna, tłum. J. Halbersztat, Wydawnictwo Naukowe PWN, Warszawa 2008, s. 16, 18. 
ukowych, ale stanowia specyficzne przedstawienia, zwiazane $z$ konkretną osobą i sytuacją. Chociaż świat i przestrzeń sa dla wszystkich takie same, to odmienna jest ich interpretacja i nasze wyobrażenia dotyczące otaczającej nas przestrzeni moga być różne. Zaczęto więc stawiać pytanie o to, jak się kształtuje nasza „wyobraźnia geograficzna” oraz w jaki sposób sa tworzone i reprezentowane nasze wyobrażenia o świecie. Coraz większą role zaczęły odgrywać badania koncentrujące się na próbach ukazania strategicznego znaczenia wyobrażeń geograficznych w działalności międzynarodowej i kształtowaniu strategii politycznej państwa.

Celem artykułu jest analiza współczesnych tendencji badawczych w geografii politycznej, a przede wszystkim usystematyzowanie wiedzy dotyczącej współczesnych badań dotyczących tak zwanych wyobrażeń geopolitycznych. Jest to obecnie jeden $z$ najczęściej poruszanych tematów w ramach geografii politycznej, ale prawie nieobecny w polskiej nauce. Ze względu na odwoływanie się do geopolityki tematyka ta budzi wiele kontrowersji, głównie ze względu na nieporozumienia, jakie przez lata narosły wokół geopolityki. Tymczasem badania nad wyobrażeniami geopolitycznymi stanowia jeden $z$ ciekawszych elementów „odrodzenia się” geografii politycznej. Badania te mają na celu analizę, w jaki sposób owe wyobrażenia są kształtowane, a także w jaki sposób moga być manipulowane i wykorzystywane, aby uzyskać legitymizację oraz lojalność społeczna wobec kierunków polityki zagranicznej, jak również wobec konfliktów zbrojnych, czystek etnicznych czy też ludobójstwa.

\section{Problem z geopolityka}

W ostatnich latach termin „geopolityka” został przywrócony do szerokiego dyskursu akademickiego i publicznego. Stało się tak przede wszystkim za sprawą badaczy/publicystów zajmujących się analiza przekształceń środowiska międzynarodowego, które nastapiły w wyniku zakończenia tak zwanej zimnej wojny i rozpadu świata 
dwubiegunowego. Obecnie jest to jedno $z$ najczęściej używanych, a zarazem nadużywanych pojęć, pojawiających się zwłaszcza w publikacjach poświęconych analizom środowiska międzynarodowego. W Polsce, podobnie jak w wielu innych krajach, występuje moda na analizy oparte na „prawach geopolityki” i powszechnie uważa się, iż myślenie geopolityczne jest wielce wartościowe, gdyż oparte jest na realizmie oraz liczeniu się $z$ międzynarodowymi układami sił i „żywotnymi” interesami mocarstw. Panuje tendencja do nazywania wszystkiego, co tylko można, „geopolityka”, a zakres semantyczny pojęcia geopolityki ewoluuje; rozszerza się, obejmując coraz to inne sfery rzeczywistości „geopolityka” wszystkiego i czegokolwiek w nadziei, że uatrakcyjni to wywód badacza.

Powrót geopolityki do obiegu akademickiego i publicystyki był i jest w dużej mierze wyrazem swoistej mody intelektualnej. Pojęcie to jest stosowane bez próby refleksji nad tym, czym właściwie jest geopolityka. Trzeba pamiętać, że ze względu na swój przedmiot badań i swoja często kontrowersyjną historię, rzadko która dziedzina budziła tak zróżnicowane odczucia i oceny, jak dzieje się to w przypadku geopolityki. Nie istnieje jednoznaczna definicja geopolityki, nie da się też dokładnie wyznaczyć jej miejsca wśród dyscyplin naukowych, nie da się określić, czy jest to w ogóle odrębna dyscyplina. Nie rozstrzygając w tym miejscu sporów i kontrowersji, które narosły wokół geopolityki trzeba przypomnieć, że geopolityka - rozumiana jako nauka, która bada relacje między cechami geograficznymi państwa a jego polityka - ukształtowała w ramach popularnego w końcu XIX wieku determinizmu geograficznego, darwinizmu społecznego i rasizmu. Widoczne jest to zwłaszcza w pracach „ojca geopolityki”, Fryderyka Ratzla, który uważał, że istota procesów politycznych jest walka o „przestrzeń życiowa" i kieruja nia prawa ekspansji analogiczne do praw kierujących wzrostem organizmu, a geografia/przestrzeń ma zasadniczy wpływ na życie narodu i państwa. Współczesne rozumienie terminu "geopolityka” jest jednak daleko odmienne od tego, które występowało w geografii politycznej końca XIX wieku. 
Myśl geopolityczna w swojej klasycznej formie była związana ze specyfika historycznego okresu określanego przez Zygmunta Baumana jako „ciężka nowoczesność”. Jak pisał Bauman, była to epoka, w której nadrzędnym celem stało się zdobycie przestrzeni: zajęcie jak największych połaci ziemi i utrzymanie ich przy sobie; czytelne oznaczenie swojej własności i otoczenie jej tablicami „Wstęp wzbroniony”. Własne terytorium było jedna $z$ największych obsesji nowoczesności, a jego zdobycie - jednym $z$ najbardziej nieodpartych pragnień. Obrona granic należała $z$ kolei do najpowszechniejszych, najsilniej utrwalonych i nieustannie rozbudzanych nowoczesnych nawyków. „Ciężka nowoczesność” była era podbojów terytorialnych. Bogactwo i władza spoczywały ukryte głęboko w ziemi, niczym obfite, rozległe i nieruchome złoża rudy żelaza lub pokłady węgla. Imperia rozrastały się, aby wchłonać każdy zakątek ziemi: granice ich ekspansji stawiały tylko inne imperia o równej im lub większej sile ${ }^{3}$.

Sprowadzając metaforyczny język Baumana na poziom realnych procesów historyczno-społecznych można stwierdzić, że rozwój myśli geopolitycznej był zwiąany $z$ dwoma ważnymi procesami europejskiej nowoczesności. Pierwszym $z$ nich była rywalizacja kolonialna między mocarstwami europejskimi o nowe terytoria i rywalizacja o supremację w środowisku międzynarodowym. Drugim zaś - proces kształtowania się nowoczesnych narodów i państw narodowych związany $z$ koniecznością określenia ich zasięgu terytorialnego. W obu tych przypadkach myśl geopolityczna odgrywała bardzo ważną rolę, choć w każdym inną. Trzeba pamiętać, iż „klasyczna geopolityka" była zjawiskiem usytuowanym w określonym kontekście historycznym, który bardzo mocno wpłynał na jej kształt. Nie można rozpatrywać roli i funkcji klasycznej myśli geopolitycznej w oderwaniu od rzeczywistości, w której się ukształtowała. Można je analizować i zrozumieć tylko poprzez ich umieszczenie w określonej rzeczywistości geograficzno-politycznej świata przełomu XIX i XX wieku.

Zob. Z. Bauman, Płynna nowoczesność, Wydawnictwo Literackie, Kraków 2006, s. 177. 
Klasyczna geopolityka, w całej swojej różnorodności, była przede wszystkim forma politycznej ideologii. Nie była nauka, mimo że twórcy myśli geopolitycznej zgłaszali roszczenia do naukowości swoich twierdzeń, kreując różnorodne „prawa geopolityczne”. Były to jednak aprioryczne, zbudowane na gruncie określonych interesów doktryny, a nie falsyfikowane teorie dotyczace istoty relacji zjawisk przestrzennych i politycznych. W tym ujęciu geopolityka nie stanowiła nauki i prace na przykład Halforda J. Mackindera, Alfreda Mahana, Karla Haushofera czy też Nicholasa J. Spykmana uchodzacych za „klasyków” myśli geopolitycznej - trudno uważać za naukowe, a tym samym trudno jest uznać geopolitykę w ich wydaniu za samodzielna dyscyplinę badawczą aspirująca do statusu naukowości. Do tego dochodzi problem zwiąany z faktem, iż „teorie” geopolityczne - takie jak na przykład teorie potęgi kontynentalnej czy też teorie mocarstw morskich - nie były i nie sa ani „neutralne”, ani "obiektywne". Rzekomą obiektywność przestrzeni traktuje się bowiem w sposób woluntarystyczny, w zależności od zapotrzebowania politycznego. Znaczenie nadawane przestrzeni geograficznej oraz rzekome „prawa” rządzące historią sa instrumentami politycznej indoktrynacji lub propagandowego uzasadniania prowadzonej polityki. Dużym problemem w przypadku wielu tak zwanych teorii geopolitycznych - na co zwracał uwage David Harvey - jest to, że niezależnie od faktu, iż koncepcja czasu i przestrzeni jest konstruktem społecznym, to operuje ona w rzeczywistości społecznej jako „obiektywny fakt”, odgrywając istotna rolę w procesach reprodukcji społecznej ${ }^{4}$. Utrudnia to dyskusję oraz racjonalna analizę pojawiających się różnorodnych „teorii geopolitycznych”.

Geopolityka największa popularnością cieszyła się w okresie między pierwszą a drugą wojną światowa. Po drugiej wojnie znalazła się jednak w niełasce i sam termin „geopolityka” niemal zniknał $z$ dyskursu naukowego. Geopolityka została bowiem uznana za narzędzie ideologiczne, którego podstawową funkcja jest legity-

4 Zob. D. Harvey, Between Space and Time. Reflections on the Geographical Imagination, „Annals of the Association of American Geographers” 1990, t. 80, nr 3, s. 418-434. 
mizacja agresywnej i ekspansjonistycznej polityki państwa. Stało się tak przede wszystkim dlatego, że rozpatrując geopolitykę przez pryzmat koncepcji jej trzech przedstawicieli - Friedricha Ratzla, Rudolfa Kjellena i Karla Haushofera - utożsamiono ja z ideologia wielkomocarstwowych Niemiec i państwa nazistowskiego, a takie powiazanie spowodowało, iż termin ten stał się ogólnym symbolem agresywnej, ekspansjonistycznej i wielkomocarstwowej ideologii. Cała geopolitykę uznano więc za niebezpieczna pseudonaukę i przypisano jej teoretyczne wspomaganie rasizmu, szowinizmu, maltuzjanizmu oraz darwinizmu społecznego, dlatego też $\mathrm{w}$ praktyce zniknęła $z$ obiegu akademickiego. Negatywna ocena związków geopolityki $z$ niemieckim faszyzmem doprowadziła do zahamowania wszelkich prób rozwoju geopolityki oraz wyjścia poza jej dotychczasowe uproszczenia.

\section{Wyobrażenia/obrazy geograficzne}

Stopniowe odrodzenie się akademickich zainteresowań geopolityka było zwiąane $z$ rekonstrukcja geografii politycznej oraz szukaniem dla niej nowych pól badawczych. Trzeba przy tym podkreślić, że geografia polityczna jest specyficzna dziedzina badań. Jako dyscyplina badająca związki zachodzące między człowiekiem i jego aktywnościa społeczna o charakterze politycznym a przestrzenia, zawsze była dyscyplina dynamiczna i odzwierciedleniem czasów, w których powstawały jej teorie ${ }^{5}$. Jako subdyscyplina geografii człowieka przeżywała wzloty i upadki, a jej tematyka i główne obszary badań ulegały $z$ upływem czasu znacznym zmianom. Narodziny geografii politycznej w jej tradycyjnej formule były zwiąane $z$ przemianami intelektualnymi i politycznymi zachodzacymi w osiemnasto- i dziewiętnastowiecznej Europie. Tradycyjna geografia polityczna koncentrowała się na państwie jako terytorialno-politycznej

5 Zob. M. Blacksell, Geografia..., s. 16, 18. 
organizacji społeczeństw ludzkich, jego granicach oraz przestrzeni jako ważnym aspekcie siły państwa w relacjach międzynarodowych.

Współczesny etap rozwoju geografii politycznej jest związany $z$ przemianami, które zaszły w ramach nauk społecznych/humanistycznych na początku lat siedemdziesiątych ubiegłego wieku. Wzrosło wówczas zainteresowanie przestrzenią w dyskursie historycznym, socjologicznym, antropologicznym, filologicznym. Pionierskie prace takich autorów jak Henri Lefevbre, David Harvey oraz Michael Foucault spowodowały, że badacze zjawisk społecznych zaczęli coraz częściej włączać aspekt przestrzenny do swoich badań oraz do wyjaśniania fenomenów społecznych. Coraz silniejszy akcent kładziono na społeczne wytwarzanie przestrzeni, to jest traktowanie jej nie jako obiektu danego, istniejącego obiektywnie, ale aktywnie kształtowanego i przekształcanego przez ludzi w zależności od ich oczekiwań i celów. Powszechne stało się przekonanie, że to, co społeczne i to, co przestrzenne stanowi nierozerwalną całość, a społeczeństwo jest „konstruowane przestrzennie” $\mathrm{i}$ ten fakt - przestrzenna organizacja społeczeństwa - wpływa na jego funkcjonowanie ${ }^{6}$.

Początkowo do rehabilitacji analiz czynnika przestrzennego $\mathrm{w}$ analizach zjawisk społecznych przyczynili się przede wszystkim francuscy badacze skupieni wokół czasopisma „Annales: Economies, Societes, Civilisations”. Szukali oni sposobu na unowocześnienie francuskiej historiografii i humanistyki w ogóle. Jedna z osób związana ze środowiskiem „Annales” był Henri Lefebvre, który w słynnej później książce, zatytułowanej Produkcja przestrzeni (La production de l'espace, 1974), zwrócił uwagę na proces społecznego wytwarzania przestrzeni oraz jej udział w reprodukcji stosunków społecznych, a także na problematykę doświadczania przestrzeni przez jej użytkowników ${ }^{7}$. Sformułował w niej tezę, że „przestrzeń społeczna jest wytworem społecznym” („[social] space is a [social] product”) ${ }^{8}$.

6 D. Massey, Space, Place and Gender, Minnesota University Press, Minneapolis 1994, s. 254.

7 Książka ta ukazała się również w języku angielskim. Zob. H. Lefebvre, The Production of Space, Blackwell, Oxford 1991.

8 Ibidem, s. 26. 
Lefebvre użył terminu „produkcja przestrzeni”, wysuwajac postulat teoretyczny głoszacy, że przestrzeń jest fundamentalnie powiązana $z$ rzeczywistościa społeczna i nie da się ich oddzielić. Wynika $z$ tego, że przestrzeń nie istnieje „sama w sobie”; jest wytwarzana i produkowana9. Przestrzeń jest wielkościa zmienną, dynamiczna, relacyjna. Nie jest po prostu przedmiotem, ale relacjami i zależnościami między podmiotami, czyli ich względnym uporządkowaniem bądź nieuporządkowaniem ${ }^{10}$. Czas i przestrzeń nie są „uniwersalne". Jako produkt społecznych praktyk moga być zrozumiane tylko w kontekście danego społeczeństwa. W tym sensie czas i przestrzeń maja charakter nie tylko relacyjny, ale także „historyczny”, co otwiera pole do analiz, które zawierają w sobie badania układów i struktur społecznych, relacji między władzą i dominacją, konfliktów społecznych, które maja znaczenie w danym momencie historycznym.

Henri Lefebvre przyczynił się do swoistego „zwrotu kulturowego” $\mathrm{w}$ badaniach $\mathrm{z}$ zakresu geografii człowieka, wyrażającego się między innymi w zwiększeniu zainteresowania „miękką” problematyka kultury: systemów wartości, znaczeń, norm i reguł, form dyskursu, mentalności zbiorowej. Nie posługiwał się jednak terminem „wyobrażenia geograficzne". Upowszechnienie się tego terminu w badaniach nad relacjami człowiek-przestrzeń trzeba przypisać Davidowi Harveyowi. Postanowił on wykorzystać koncepcję „wyobraźni socjologicznej" Charlesa W. Millsa oraz zastosować ją do badań nad przestrzenią i miejscem. Określił „wyobraźnię geograficzną” jako swoista „świadomość przestrzenną, która umożliwia jednostce rozpoznanie roli przestrzeni oraz umieszczenie jej we własnym doświadczeniu i biografii. Pozwala ona na umiejscowienie się w przestrzeni, która jednostka widzi wokół siebie, a także na zrozumienie, w jaki sposób przestrzeń, która dzieli jednostki od siebie, wpływa na ich interakcje. Jak pisał, jest to umiejętność pozwalająca jednostce rozpoznać związek, który istnieje między nią a jego sąsiedztwem i jego

\footnotetext{
9 Ch. Schmid, Henri Lefebure's Theory of the Production of Space. Towards a Three-Dimensional Dialectic, w: Space, Difference, Everyday Life. Reading Henri Lefebvre, red. K. Goonewardena i in., Routledge, London - New York 2008, s. 28.

10 H. Lefebvre, The Production.., s. 73.
} 
terytorium, umożliwiająca jej ocenę wydarzeń zachodzących w innych miejscach oraz stwierdzenie, czy sa one dla niej istotne, czy też nie. Wyobraźnia ta pozwala także na twórcze przekształcenia przestrzeni oraz na docenienie znaczenia form przestrzennych stworzonych przez innych ${ }^{11}$. Harvey zwracał uwagę, że „wyobraźnia geograficzna" manifestuje się w wielu sferach aktywności ludzkiej i jest ważnym elementem dla architektów, artystów, planistów, socjologów, politologów, antropologów, historyków, ekonomistów, a także filozofów i oczywiście geografów. Można stwierdzić, że „świadomość przestrzenna” (Harvey) jest umiejętnością konieczną do „społecznej produkcji przestrzeni” (Lefebvre). Harvey chciał ukazać wpływ „świadomości przestrzennej” na percepcyjne i symboliczne przestrzenie codziennego życia i był przekonany, że relacje między procesami społecznymi a formami przestrzennymi muszą być lepiej rozpoznane i zrozumiane, gdyż jest to wstępny warunek dla krytycznych badań nad urbanizacją, modernizacją, dyfuzją kulturowa, migracjami, międzynarodowymi przepływami kapitału, rozwojem regionalnym, problemami geopolitycznymi oraz wielu innymi istotnymi kwestiami ${ }^{12}$.

Koncepcje Harveya okazały się inspirujące dla wielu geografów, a pojęcie wyobraźni geograficznej / świadomości przestrzennej weszło na stałe do repertuaru badań geograficznych. Zostało ono poddane dyskusji i stopniowo ewoluowało, zmieniając swoja treść i przyczyniając się sformułowania kategorii „wyobrażenia/obrazy geograficzne”. Było to efektem uznania, że „wyobraźnia przestrzenna" jednostki, czy też określonej zbiorowości, jest także konstruktem społecznym, a nasza wiedza o przestrzeni nie jest wiedza obiektywna/neutralną. Na przykład Derek Gregory w swojej pracy Geographical Imagination (1994) definiował wyobrażenia geograficzne jako system kulturowo i historycznie usytuowanej wiedzy geograficznej, która charakteryzuje określona grupę społeczną ${ }^{13}$. Dy-

\footnotetext{
11 D. Harvey, The Sociological and Geographical Imaginations, „International Journal of Politics, Culture and Society" 2005, t. 18, s. 212.

12 Ibidem.

13 Derek Gregory podją próbę dekonstrukcji terminu „orientalizm” wskazując, że europejskie pojmowanie Orientu w różnorodnych publikacjach, a także na fotografiach i mapach,
} 
mitr Zamiatin w książce Власть пространства и пространство власти (2004) pisał natomiast o geograficznych obrazach, które powstaja w wyniku krzyżowania się i współoddziaływania pojęć geograficznych i parageograficznych $\mathrm{w}$ procesie kształtowania się języka. Obrazy te - będąc pewnymi uproszczeniami i stereotypami dotyczacymi otaczajacej nas przestrzeni - służą ekonomizacji naszego myślenia, dostarczając nam gotowych szablonów poznawczych ${ }^{14}$. Dostarczaja one swoistej dla danej grupy społecznej mapy świata i stanowia jeden $z$ elementów kulturowo-politycznej samoidentyfikacji. Stanowia pewien sposób, w jaki wpływowe grupy społeczne definiuja państwo, naród i świat. Są to zatem wyobrażenia lokujace dane państwo i zbiorowość w przestrzeni globalnej, dzięki ich znajomości można zrozumieć sposoby identyfikacji narodowej, tworzenia granic, znaczenie pojęć „tu” - „tam”, „my” - „oni” ${ }^{\text {. }}$. System dominujacych w danym społeczeństwie obrazów geograficznych kreuje specyficzna przestrzeń geograficznych wyobrażeń (przestrzeń metageograficzna), które stanowia podstawę do uformowania się geopolitycznych i polityczno-geograficznych wyobrażeń charakterystycznych dla danej grupy społecznej.

Koncepcje Lefebvre'a „społecznego konstruowania przestrzeni” i Harveya „wyobraźni geograficznej” okazały się bardzo inspirujące, przyczyniając się do odrodzenia zainteresowania badaczy przestrzennymi aspektami procesów społecznych. Dzięki pracom tych autorów pojęcie wyobrażeń geograficznych weszło na stałe do badań społecznych, występując w różnych kontekstach ${ }^{16}$. Bardzo szybko się okazało, że koncepcje te sa niezwykle użyteczne w analizach

jest tylko pewnego rodzaju geograficznym wyobrażeniem, kształtowanym $z$ europocentrycznego punktu widzenia. Zob. D. Gregory, Geographical Imagination, Blackwell, Cambridge (Mass.) 1994.

14 Д.Н. Замятин, Власть пространства и пространство власти, РОССПЭН, Москва 2004, s. 324.

15 G. O'Tuathail, Geopolitical Structures and Cultures. Towards Conceptual Clarity in the Critical Study of Geopolitics, w: Geopolitics. Global Problems and Regional Concerns, red. L. Tchantouridze, University of Manitoba, Winnipeg 2004, s. 84.

16 Zob. J.J. Gieseking, Geographical Imagination, w: International Encyclopedia of Geography. People, the Earth, Environment, and Technology, red. D. Richardson i in., Wiley - Blackwell, New York 2017, s. 2657-2661. 
i rozumieniu procesów społecznych, w tym także tych o charakterze politycznym, jak na przykład rywalizacja między dużymi zbiorowościami ludzkimi skupionymi w państwa i narody. Przyjęcie perspektywy geografii humanistycznej - koncentrującej się na interakcjach między populacjami ludzkimi a przestrzenią, w której przebiega aktywność społeczno-polityczna - pozwoliło na odrodzenie się akademickiego zainteresowania geografia polityczna, przed która otworzyły się nowe interesujące perspektywy badawcze. Odrodzenie się geografii politycznej spowodowało także przywrócenie zainteresowania geopolityką.

\section{Od „wyobrażeń geograficznych" do „wyobrażeń geopolitycznych" - Yves Lacoste i czasopismo "Hérodote"}

Badaczem, który wywarł chyba największy wpływ na współczesne odrodzenie się akademickich zainteresowań geografia polityczna i geopolityka był francuski geograf Yves Lacoste, profesor geografii na Uniwersytecie Vincennes. To on zaproponował przeniesienie kategorii wyobrażeń geograficznych na obszar analiz procesów politycznych. To również on uczynił $z$ "wyobrażeń przestrzennych" główny element analiz z zakresu geografii politycznej, przyczyniając się pośrednio także do rehabilitacji geopolityki. Jego oryginalne podejście do analiz z zakresu geografii politycznej i geopolityki było pierwotnie efektem nie tyle nowatorskiego projektu badawczego, ile raczej zaangażowania ideologicznego. Lacoste należał bowiem do młodego pokolenia francuskich badaczy, których idee kształtowały się w bardzo specyficznej atmosferze polityczno-społecznej Francji końca lat sześćdziesiątych ubiegłego wieku. Wówczas to, na fali kontestacji, nastapił w naukach społecznych gwałtowny wzrost zainteresowania radykalizmem i krytycyzmem. Ważnym elementem tego podejścia było założenie, iż radykalizm i krytycyzm w bada- 
niach społecznych muszą się łączyć z postawą czynną oraz działaniem zmieniajacym to, co jest uznane za zło. Celem poznania jest bowiem nie tylko odpowiedź na pytanie, jak jest. Wiedza ma ukazywać ukryte mechanizmy władzy i zniewolenia, aby można było się im skutecznie przeciwstawić.

Lacoste przeniósł postawę radykalną do badań geograficznych. Uważał, że rola geografów powinna polegać na wykorzystywaniu umiejętności myślenia przestrzennego do tego, aby działać efektywniej i skuteczniej. Należał do grupy młodych badaczy, takich jak Jean Dresch czy Pierre George, którzy podjęli próbę odnowy i reorientacji francuskiej geografii. Uważał, że w przeszłości geografia była na usługach „politycznej dominacji, nowoczesnych wojen oraz kontrrewolucji" ${ }^{17}$. Jego ideałem - jako osoby związanej $z$ francuska lewica i nawiąujaccej do tradycji marksistowskiej - była natomiast wiedza geograficzna służąca emancypacji człowieka i pozwalająca na ukazywanie mechanizmów władzy, tak aby móc się jej przeciwstawić oraz budować lepsze społeczeństwo. Uważał, że geografia jako dyscyplina akademicka znajduje się w kryzysie, ponieważ koncentrując się tylko na opisie krajobrazu, unika konfrontacji $z$ rzeczywistymi problemami świata, a tym samym nie może się stać dyscypliną użyteczną w rozwiązywaniu i wyjaśnianiu różnorodnych problemów społecznych.

Zaangażowanie polityczno-ideologiczne nie przeszkodziło Lacoste'owi we wprowadzeniu do geografii politycznej interesujacych elementów, które do dziś wyznaczaja główne kierunki zainteresowań badawczych tej dyscypliny. Lacoste, kierujac się swoją wizja geografii politycznej, powołał do życia w 1976 roku czasopismo zatytułowane „Hérodote”, poświęcone problematyce geografii politycznej i geopolityki. Miało ono służyć realizacji programu odnowy geografii i wkrótce stało się jednym $z$ najważniejszych periodyków poświęconych tej dziedzinie. Rozpoczynając realizację projektu „Hérodote”, Lacoste chciał wyprowadzić geografię $z$ peryferii do centrum debaty dotyczącej społecznych i politycznych problemów współczesnego świata.

17 Y. Lacoste, Editorial, „Hérodote” 1976, nr 1, s. 1-2. 
Badacze skupieni wokół „Hérodote” koncentrowali się na takich elementach wiedzy geograficznej, jak na przykład mapy rozumiane jako podstawowa forma opisania i uporzadkowania przestrzeni, historia (gdyż uważano, że każda przestrzeń geograficzna czy też społeczna jest kształtowana i przeobrażana przez ludzi w procesie historycznym), granice dzielace przestrzeń globalna i proces ich kształtowania, a także analiza wyobrażeń geograficznych i historycznych zawartych w atlasach i podręcznikach szkolnych, wystąpieniach polityków czy oficjalnych dokumentach. Lacoste uważał, że „czynniki geograficzne” pozostaja aktywnym i ważnym aspektem działalności politycznej. Nawiązując do Foucaultowskiej koncepcji wiedzy-władzy, uznał geografię za wiedzę, która wytwarza i utrwala określony obraz świata, skrywając go za „dymna zasłona” nauki akademickiej. Geografia pełni rolę ideologiczna, dostarczając obywatelom wiedzy na temat ich państwa, otoczenia i świata zewnętrznego, budując ich wiedzę o świecie i będąc tym samym dyscyplina polityczno-strategiczną.

„Nowa geografia” postulowana przez twórców „Hérodote” miała przekroczyć ograniczenia związane $z$ jej dotychczasową rolą oraz stać się krytyczna analiza, która powinna ukazać rolę geografii w wytwarzaniu władzy i narzucaniu odpowiedniego obrazu świata ${ }^{18}$. Niezależnie od wyraźnie ideologicznego nastawienia i politycznego zaangażowania po stronie francuskiej lewicy Lacoste zaproponował nowatorskie podejście do zagadnień geografii politycznej. Podkreślał, że z punktu widzenia geografii przestrzeń nie jest „neutralnym” składnikiem naszego doświadczenia społecznego. Jest bowiem miejscem rywalizacji, w której klasy społeczne, grupy kapitałowe, wojsko, administracja państwowa przeciwstawiają się sobie; spierają o terytoria, które sa stawką w grze o dominację $e^{19}$.

Dzięki swojemu podejściu do problematyki geografii politycznej środowisko naukowców skupionych wokół czasopisma „Hérodote”

\footnotetext{
18 L.W. Hepple, Geopolitiques de Gauche. Yves Lacoste, Hérodote and French Radical Geopolitics, w: Geopolitical Traditions. A Century of Geopolitical Thought, red. K. Dodds, D. Atkinson, Routledge, London 2000, s. 268, 273.

19 Y. Lacoste Attention: geographie!, „Hérodote” 1976, nr 1, s. 3-4.
} 
przyczyniło się także do odrodzenia zainteresowania badaczy akademickich geopolityka. Lacoste definiował geopolitykę jako "całokształt rywalizujących sił na danym terytorium”. Uważał, że termin „geopolityka” odnosi się do wszystkiego, co ma związek z rywalizacją o władzę lub wpływy nad jakimś terytorium i zamieszkująca ja ludnościa; rywalizacja pokojową lub przy użyciu przemocy, toczona między różnego rodzaju siłami politycznymi - nie tylko państwami, lecz również wewnątrz nich, między ruchami politycznymi, między mniej lub bardziej legalnymi grupami zbrojnymi czy też, inaczej mówiąc, wszelkimi ośrodkami władzy, także tymi pozostającymi w ukryciu. Rywalizacja ta toczy się o kontrolę, czy dominację, nad terytoriami geograficznymi - nieważne, czy sa rozległe, czy całkiem niewielkich rozmiarów ${ }^{20}$. Dla Lacoste'a zjawiska i procesy o charakterze geopolitycznym stanowiły wyraz rywalizacji o władzę nad określonym terytorium.

Kiedy mowa jest o geopolityce, to tak naprawdę mówimy o walce o władzę nad określona przestrzenią oraz o ludziach, którzy żyja na danym obszarze. W konfrontacji sił politycznych każda $z$ nich wykorzystuje rozmaite środki i argumenty, aby uzasadnić, że to właśnie ona ma szczególne prawo do władzy nad danym terytorium, a żądaniom przeciwników brakuje dostatecznych podstaw ${ }^{21}$. W każdym momencie historycznym sytuacja geopolityczna jest określana przez rywalizację o władzę (w większych lub mniejszych rozmiarach) oraz przez stosunki między siłami, które znajduja się na terytorium, o które toczy się rywalizacja. Przy czym metoda analizy geopolitycznej i refleksja historyczna sa od siebie nierozdzielne. Nie można dokonywać analizy sytuacji geopolitycznej bez odniesienia do historii. W rzeczywistości wszystko, co można przedstawić na mapach o różnej skali czy też, inaczej mówiąc, na każdym poziomie analizy przestrzennej - linie granic, zachodzące na siebie terytoria różnych ludów i ich języków, nierównomierne rozmieszczenie ludności itd.

20 Y. Lacoste, Geopolityka Śródziemnomorza, Wydawnictwo Akademickie Dialog, Warszawa 2010, s. 15, 17.

21 Por. P. Lorot, Historie da la géopolitique, Economica, Paris 1995, s. 69. 
- wynika $z$ dawnych układów sił, które utrzymywały się krócej lub dłużej. Kwestia podstawowa jest zrozumienie aktualnych konfliktów poprzez kojarzenie obrazujacych je map $z$ analiza obecnych skutków dawnych wydarzeń, które nastąpiły przed kilkoma miesiącami, latami czy wręcz stuleciami. Nie można zrozumieć, nawet w najogólniejszym zarysie, danej sytuacji geopolitycznej bez wiedzy o tym, jak do niej doszło, to znaczy bez ogólnej wiedzy o konfliktach władzy, które następowały po sobie na danym terytorium ${ }^{22}$.

Lacoste uważał, iż każdym momencie historycznym sytuacja geopolityczna jest określana przez rywalizację o władzę oraz przez stosunki między siłami, które znajduja się na terytorium, o które toczy się rywalizacja. Inaczej mówiąc: sytuacja geopolityczna jest wytwarzana i dana w określonym okresie historycznej ewolucji przez rywalizujące ze soba potęgi i relacje sił, które sa ulokowane na różnych obszarach danego terytorium ${ }^{23}$. Tym, co w dużym stopniu charakteryzowało specyfikę geopolityki Lacoste'a był także fakt, iż uczony ten uważał, że państwa rywalizuja o dane terytoria nie tylko dlatego, że znajduja się tam określone bogactwa, ale przede wszystkim $z$ tego powodu, iż terytoria te maja znaczenie „symboliczne”. Dana przestrzeń może stanowić dla danego podmiotu geopolitycznego określoną wartość symboliczną $z$ punktu widzenia narodowego, etnicznego czy też religijnego. Aktorzy polityczni kieruja się $\mathrm{w}$ swoich działaniach partykularnymi wyobrażeniami i przedstawieniami świata, które stanowia jedna z głównych determinant aktywności geopolitycznej.

Dla Lacoste'a wiedza geograficzna, dostarczająca obywatelom informacji na temat ich państwa, otoczenia i świata zewnętrznego, pełni rolę ideologiczno-polityczna. Według francuskiego uczonego wiedza ta jest w swojej istocie typowa wiedza o charakterze politycznym. We wprowadzeniu do Dictionnaire de géopolitique pisał, że należy łączyć badania poświęcone ideom geopolitycznym $z$ analiza geopolitycznej sytuacji, w której one powstaja. Geopolityka to

\footnotetext{
Y. Lacoste, Geopolityka Śródziemnomorza..., s. 21-22.

23 Dictionnaire de géopolitique, red. Y. Lacoste, Flammarion, Paris 1993, s. 3.
} 
$\mathrm{w}$ swej istocie zideologizowana wiedza, tworzona przez podmioty geopolityczne, przedstawiająca współzależności $z$ innymi podmiotami działajaccymi na arenie międzynarodowej w funkcji swych interesów. Nie istnieją żadne „prawa geopolityczne”, gdyż występują one tylko w subiektywnie określonej, podmiotowej myśli geopolitycznej oraz służą do tworzenia hipotez, teorii, przedstawień i scenariuszy politycznych; te $z$ kolei sa zależne od interesów i posiadanej technologii oraz od systemu wartości kulturowych właściwych temu, kto je opracowuje. Lacoste uważał, iż analiza przyjętych partykularnych wizji świata pozwala zrozumieć, co determinuje wybór określonej strategii politycznej. Dlatego też francuski uczony centrum swoich zainteresowań uczynił kategorię „wyobrażeń geopolitycznych”, która według niego może być kluczem do zrozumienia konfliktów terytorialnych między grupami ludzkimi. Uważał bowiem, iż aby zrozumieć charakter konfliktów geopolitycznych, trzeba dotrzeć do kluczowych idei i wyobrażeń leżacych u ich podstaw ${ }^{24}$. Sądził również, że takie pojmowanie geopolityki pozwoliłoby na uznanie jej za samodzielną dyscyplinę badawcza, zajmująca się wyodrębnianiem oraz systematyczną konfrontacja spostrzeżeń i przekonań, jakie każda grupa polityczna posiada na temat przestrzeni.

Idee Lacoste'a znalazły szeroki oddźwięk w środowisku geografów. Nawiązując do teorii krytycznej, a także do poststrukturalizmu i postmodernizmu, zaczęto podkreślać fakt, iż tak zwane teorie geopolityczne nie sa prawda absolutna, ale partykularnymi przedstawieniami związanymi $z$ konkretna osoba i sytuacją. Zgodnie $z$ podejściem krytycznym wiedza nie jest i nie może być neutralna - ani pod względem moralnym, ani politycznym, ani ideologicznym. Każda wiedza odzwierciedla interesy obserwatora. Nigdy nie jest bezstronna, ponieważ jest wytworem perspektywy społecznej badacza. Zaczęto więc zadawać pytanie o to, jak się kształtuje nasza swoista „wyobraźnia geopolityczna” oraz w jaki sposób ludzie nabywaja i tworzą swoje wyobrażenia o otaczajacym ich świecie. Stopniowo

${ }_{24}$ Por. Y. Lacoste, Une monde qui n'est pas futile, w: Le monde: espaces et systèmes red. V.F. Durand, J. Levy, D. Retaile, Presses de Science Po, Dalloz, Paris 1993, s. 70-74. 
w centrum badań postawiono problematykę partykularnych sposobów postrzegania świata kształtowanych w procesach dyskursu społecznego.

\section{„Wyobrażenia geopolityczne”}

Yves Lacoste wywarł wielki wpływ na odrodzenie się geografii humanistycznej oraz przywrócił zainteresowanie geografów zagadnieniami geopolitycznymi, czyli rolą, jaką odgrywa przestrzeń w rywalizacji politycznej między zbiorowościami ludzkimi. Szczególnie duże zainteresowanie badaczy przyciagnęła idea badania „wyobrażeń geopolitycznych" oraz ich roli i znaczenia w kształtowaniu aktywności politycznej. Dzięki temu zaczęły powstawać liczne prace poświęcone „wyobrażeniom geopolitycznym”, a przedstawiciele tak zwanej geopolityki krytycznej podjęli w swoich badaniach próbę zrozumienia, w jaki sposób te wyobrażenia sa kształtowane i utrwalane w zbiorowej pamięci.

Od lat dziewięćdziesiątych ubiegłego wieku powstała olbrzymia liczba prac poświęconych „wyobrażeniom geopolitycznym”, wśród których kilka zasługuje na szczególną uwage, gdyż na ich przykładzie można dokonać analizy podstawowych idei zwiazanych $z$ badaniem tych „wyobrażen". Jedna $z$ charakterystycznych prac poświęconych tej problematyce była ksiażka Gertjana Dijkinka National Identity and Geopolitical Visions (1996), w której holenderski uczony analizował problemy wyobrażeń geopolitycznych, tożsamości narodowej, kultury geopolitycznej oraz geopolitycznych tradycji Wielkiej Brytanii, Stanów Zjednoczonych, Niemiec, Rosji, Iraku, Serbii, Argentyny, Australii i Indii, ukazując na przykładzie tych państw, w jaki sposób manifestują się różnorodne wyobrażenia przestrzenne w różnych częściach świata. Dijkink zdefiniował termin „wyobrażenia geopolityczne” jako idee, które odnosza się do relacji między czyjaśs własna przestrzenia (miejscem) a pozostałym światem, obejmujące odczucie bezpieczeństwa/zagrożenia, przewag/słabości 
i/lub odwołujące się do idei dotyczących narodowego (kolektywnego) przeznaczenia lub do strategii polityki zagranicznej25. Znaczenie nadane temu terminowi przez Dijkinka było szerokie i elastyczne, gdyż wskazywał on, iż przez pojęcie wyobrażeń geopolitycznych można rozumieć wszelkie idee odnoszące się do relacji między „własną" a pozostałymi - „obcymi” - przestrzeniami i miejscami, zwiazane $z$ poczuciem bezpieczeństwa/zagrożenia czy też przewagi/słabości lub też zwianych $z$ ideami dotyczacymi „misji narodowej” realizowanej poprzez politykę zagraniczną. I wreszcie pojęcie wizji geopolitycznych odnosi się do rozróżnienia my-oni oraz związków emocjonalnych $z$ określonym terytorium. „Wyobrażenia geopolityczne” to zespół wyobrażeń przestrzennych zwiazanych $z$ daną grupa oraz wyznaczających w dużym stopniu ich tożsamość i miejsce w świecie. Nie sa one atrybutem wyłącznie państwa, ale także grup pozbawionych formalnej organizacji państwowej, jak na przykład Kurdów. Geopolityczne wizje są sposobem tłumaczenia i przenoszenia koncepcji narodowo-tożsamościowych na język geograficznych terminów i symboli budujących określoną mapę świata ${ }^{26}$.

Ogólnie rzecz ujmując, książka Dijkinka była poświęcona „narodowemu doświadczeniu miejsc" (ang. the national experience of place), czyli temu, jak poszczególne państwa, a ściślej rzecz ujmując, jak narodowe elity definiuja to, kim sa, jakie jest ich miejsce w świecie oraz jak to wpływa na ich stosunki $z$ innymi państwami/elitami. Słabościa tej książki było przede wszystkim to, że każdej z analizowanych przez siebie społeczności autor przypisał jedna określona „wizję” świata. Tworzyło to wrażenie, jakby poszczególne grupy miały jedna, dominujaca „wizję geopolityczną. Dijkink, koncentrujac się na dość szerokiej analizie wybranych zbiorowości, wydawał się całkowicie ignorować fakt, że kultura każdej zbiorowości jest tworem złożonym, w którego ramach można wyodrębnić wiele różnorodnych sposobów postrzegania świata. Na szczęście powstały także inne prace, które

${ }_{25}$ G. Dijkink, National Identity and Geopolitical Visions. Maps of Pride and Pain, Routledge, London 1996, s. 11.

26 Ibidem, s. 11-15. 
nie powielały podejścia Dijkinka. Ich autorzy skupili się bowiem na przedstawieniu złożonego obrazu „wyobrażeń geopolitycznych” funkcjonujących w ramach danej zbiorowości i charakterystycznej dla niej kultury. Do najbardziej znaczących prac tego typu należa publikacje rosyjskiego geografa Dymitra Zamiatina oraz brytyjsko-izraelskiego badacza Davida Newmana. Szczególnie interesujace sa prace tego pierwszego autora ze względu na ich oryginalne i nowatorskie podejście do problematyki „wyobrażeń geopolitycznych”. Wartościowa poznawczo jest zwłaszcza przywoływana już książka Dymitra Zamiatina zatytułowana Włast' prostranstwa i prostranstwo własti: geograficzeskije obrazy $w$ politikie i mieżdunarodnych otnoszenijach, w której autor podjął się analizy podstawowych obrazów geopolitycznych dominujacych w rosyjskiej kulturze oraz przedstawienia obrazów geograficznych obecnych w rosyjskim społeczeństwie, a także mitów zwiazanych $z$ rosyjska przestrzenia $i$ ich wpływu na postrzeganie świata. Wychodząc $z$ założenia, iż otaczająca człowieka przestrzeń jest wytworem społecznym (społecznie konstruowanym), głównym polem zainteresowań Zamiatina jest kształtowanie się obrazów geograficznych oraz ich wpływ na życie społeczne, a także na podejmowane decyzje polityczne. Rosyjski badacz zwraca uwagę, że system obrazów geograficznych dominujących w danym społeczeństwie kreuje specyficzna przestrzeń geograficznych wyobrażeń (przestrzeń metageograficzna), które stanowia podstawę do uformowania się przekonań geopolitycznych i polityczno-geograficznych danej grupy społecznej. Aby zatem zrozumieć politykę zagraniczna Rosji, trzeba zrozumieć, w jaki sposób Rosjanie postrzegaja samych siebie i świat zewnętrzny, jaka jest geopolityczna mapa świata funkcjonujaca w wyobrażeniach rosyjskich elit i społeczeństwa oraz w jaki sposób kształtuje się rosyjska „wyobraźnia geopolityczna”.

Wychodząc $z$ założenia, iż tożsamość każdego kraju zawiera w sobie obrazy, wyobrażenia, a także postrzeganie otoczenia zewnętrznego, innych krajów i społeczności, na którego podstawie kształtuje się przeciwieństwo „my” - „oni”, Zamiatin uczynił osią siatki badawczej swoich geopolitycznych analiz pojęcie obrazów geopolitycz- 
nych (ros. geopoliticzeskij obraz - GPO). Przez pojęcie to rozumiał on ukierunkowane i wyraźnie ustrukturyzowane przedstawienia (wyobrażenia) o geograficznej przestrzeni, zawierające najbardziej wyraziste i zachowane w pamięci zbiorowej symbole, znaki, obrazy i charakterystyczne cechy określonych terytoriów, krajów, regionów, znakujące je $z$ politycznego punktu widzenia. GPO stanowa swojego rodzaju polityczny „metaobraz” leżący u podstaw działania politycznego. Zamiatin uznał, iż najważniejszą rolę pełnią tak zwane kluczowe obrazy geopolityczne, które w największym stopniu strukturyzują wyobraźnię przestrzenno-polityczną. Obrazy geopolityczne - jako kluczowa dla danego społeczeństwa forma opisania i uporządkowania przestrzeni za pomoca geopolityki - sa przenoszone na realna polityczna mape świata, stając się podstawą do pojawienia się specyficznych i partykularnych - to jest odnoszacych się do określonej rzeczywistości polityczno-kulturowej - koncepcji geopolitycznych ${ }^{27}$.

Szczególnie interesujace i wartościowe u Zamiatina było to, że w odróżnieniu od Dijkinka - nie traktował on kultury danego społeczeństwa jako jednolitego systemu wyobrażeń, ale podjął się analizy właściwości i prawidłowości kształtowania się oraz funkcjonowania sieci obrazów geograficznych na różnych poziomach społecznej i politycznej aktywności człowieka. Podkreślał przy tym, iż przedstawienia i obrazy świata zewnętrznego nie sa statyczne, ale zmieniaja się w zależności od przemian zachodzących zarówno w kraju, jak i w postrzeganych podmiotach. Analizował dynamike geopolitycznych obrazów we współczesnej Rosji w latach 1991-2001, a więc w okresie decydujacym dla ukształtowania się obecnej rosyjskiej tożsamości. Wskazał na kluczowe geopolityczne obrazy Rosji, które $\mathrm{w}$ największym stopniu kształtują wyobraźnię geopolityczna Rosjan, a tym samym pośrednio ich zachowania w środowisku międzynarodowym. Wśród kluczowych geopolitycznych obrazów Rosji wymienił wyobrażenia: (1) „Rosja - wyspa”; (2) Rosja - Eurazja;

27 Рог. Д.Н. Замятин, Власть пространства..., s. 43-53. 
(3) Rosja i Europa, czyli Rosja jako Europa; (4) Rosja jako Bizancjum oraz (5) Rosja jako Europa Wschodnia. Podkreślał przy tym, iż konceptualizacja geopolitycznej przestrzeni Rosji jest zwiąana przede wszystkim $z$ charakterem tych kluczowych obrazów geopolitycznych zakorzenionych w świadomości społecznej ${ }^{28}$.

Zamiatin nie poprzestał na analizie "obrazów geopolitycznych" funkcjonujących w rosyjskiej przestrzeni kulturowej, ale starał się także ukazać ich znaczenie praktyczne, czyli jak sa one wykorzystywane w rzeczywistości politycznej. Ważna część jego pracy stanowiła analiza na poziomie mikro poświęcona związkom zachodzacym między wyobrażeniami przestrzennymi a kultura polityczna społeczeństwa, rozwojem współczesnego rosyjskiego federalizmu oraz dynamika kształtowania się obrazów centrum i regionów Federacji Rosyjskiej ze zmienionej sytuacji społeczno-politycznej przełomu XX i XXI wieku, kiedy to w Rosji nastapiło odejście od centralizacji władzy, osłabianie więzi państwowych na rzecz budowy więzi globalnych i regionalnych ${ }^{29}$. W mojej ocenie praca Zamiatina jest jedna z najciekawszych i najoryginalniejszych, które zostały poświęcone „wyobrażeniom geopolitycznym”. Autor ten, analizując rosyjskie „obrazy geopolityczne”, starał się także wskazać na ich rolę w aktywności politycznej człowieka twierdzac, iż ukierunkowują one nasze działania, dostarczając nam swoistej mapy świata. Co więcej, nawiązujac do geopolityki krytycznej, wskazywał na kontekstowość wyobrażeń i idei geopolitycznych, które nie maja charakteru uniwersalnego, ale partykularny, zwiazany $z$ konkretnym czasem i miejscem.

Bardzo charakterystyczne dla analiz „wyobrażeń geopolitycznych" sa też prace Davida Newmana. Ten urodzony w Londynie i pracujacy na izraelskim Uniwersytecie Ben-Guriona geograf specjalizuje się $\mathrm{w}$ przede wszystkim w badaniach nad problematyka granic oraz konfliktem izraelsko-palestyńskim. W jego pracach pojawiły się bardzo interesujace wątki związane $z$ rolą, jaką odgrywa- 
ja „wyobrażenia geopolityczne” w procesach rywalizacji politycznej. Neuman podkreślał dynamiczny charakter tych wyobrażeń. Pisał, że w tym sensie państwa, jako organizacji terytorialnej, nie można traktować jako statycznego obiektu zajmujacego jednoznacznie określone miejsce $\mathrm{w}$ niezmiennej strukturze geopolitycznej. Wyobrażenia geopolityczne elit, obywateli i grup, które związały swój los z danym państwem odzwierciedlaja różnorodne lokalizacje na poziomie zarówno globalnym, jak i regionalnym. Cechy charakterystyczne poszczególnych grup oraz ich miejsce w strukturze społecznej odgrywają decydująca rolę $\mathrm{w}$ kształtowaniu się wyobrażeń geopolitycznych. Im bardziej homogeniczne społeczeństwo, tym silniej także wyobrażenia staja się bardziej homogeniczne. Im natomiast społeczeństwo jest bardziej złożone i zróżnicowane, tym większa istnieje w nim różnorodność wyobrażeń geopolitycznych. Przy czym ogólna percepcja świata i „innych" jest efektem procesów socjalizacji polityczno-kulturowej ${ }^{30}$.

Podkreślając dyskursywny charakter geopolityki, Newman twierdził, że zrozumienie, w jaki sposób dany kraj pozycjonuje się w ramach systemu światowego wymaga zrozumienia wewnętrznego dyskursu dotyczącego tożsamości danego społeczeństwa i kraju. Jest to zatem „rozumiejace” spojrzenie na geopolitykę „od dołu”, a nie z perspektywy „systemu globalnego” oderwanej od realiów kulturowych danego kraju ${ }^{31}$. Jako przykładu służącego zilustrowaniu swoich tez użył państwa Izrael. Wskazywał, że w tym przypadku istnieja dwa zasadnicze pytania dotyczace obywatelstwa i tożsamości. $Z$ jednej strony jest to pytanie o to, „kto jest Izraelita”, to znaczy obywatelem Izraela / częścia jego wspólnoty (Who is an Israeli)?, a $z$ drugiej strony „gdzie jest Izrael? (Where is Israel?) ) $^{32}$. Wskazał na pięć dominujących sposobów definiowania miejsca państwa Izrael $\mathrm{w}$ świecie (Where is Israel?) i powiazał je $z$ konkretnymi grupami

30 D. Neuman, Citizenship, Identity and Location. The Changing Discourse of Israeli Geopolitics, w: Geopolitical Traditions..., s. 303.

${ }_{31}$ Ibidem, s. 304.

32 Ibidem, s. 306. 
społecznymi. Ich wyodrębnienie było pewnym zabiegiem analitycznym, gdyż te „czyste typy” w rzeczywistości się przenikają, tworząc złożony kolaż wyobrażeń. Sa to: (1) „Na Bliskim Wschodzie”, jako część swojego geograficznego regionu. Wsparcie dla tej koncepcji pochodzi przede wszystkim od osób urodzonych na Bliskim Wschodzie i nie mających innych doświadczeń kulturowych; (2) „W Europie”, obraz rozumiany kulturowo jako część tradycji i historii europejskiej i sytuujący się gdzieś „między Paryżem a Pragą. Jest to bardzo silne wyobrażenie, gdyż bazę społeczną stanowią osoby (i ich potomkowie) będące założycielami państwa Izrael, a pochodzące głównie $z$ Europy Środkowo-Wschodniej. Obecnie obraz ten uzyskuje wsparcie zwłaszcza wśród nowych migrantów $z$ obszarów byłego ZSRR; (3) „Kraj bez granic”, jako część wielkiej żydowskiej diaspory. Tak postrzegany jest głównie w licznych żydowskich diasporach na świecie; (4) „Pięćdziesiąty pierwszy stan USA”, obraz rozumiany jako najbliższy sojusznik Stanów Zjednoczonych i jedyna demokracja na Bliskim Wschodzie. Ta koncepcja jest wspierana przez silne lobby amerykańsko-żydowskie; (5) „Centrum świata”, jako „Święta Ziemia” i miejsce narodzin trzech wielkich religii monoteistycznych. Obraz ten występuje głównie wśród wspólnot religijnych, ale także $\mathrm{w}$ ruchach szukających sposobu na zakończenie konfliktu izraelsko-palestyńskiego ${ }^{33}$.

Analizując pojawiające się w literaturze teksty poświęcone „wyobrażeniom geopolitycznym”, można dokonać pewnych uogólnień, które pozwalaja na zrozumienie fenomenu owych „wyobrażeń" oraz ich wartości heurystycznej. Po pierwsze - każda grupa społeczna, każda wspólnota polityczna wykształca w toku swojego rozwoju pewne wyobrażenia o otaczajacym ja świecie oraz własnym miejscu w nim. Przedstawienia (wyobrażenia, narracje) o geograficznej przestrzeni (zawierajace najbardziej wyraziste i zachowane w pamięci zbiorowej symbole, znaki, obrazy i charakterystyczne cechy określonych terytoriów, krajów, regionów) odgrywają ważna

33 Ibidem, s, 317-332. 
rolę $\mathrm{w}$ budowaniu tożsamości grupowej. Wyobrażenia przestrzenne stanowia element grupowej wiedzy o otaczajacym nas świecie, dostarczaja nam swoistej „mapy świata”, sa ważnym składnikiem zbiorowej tożsamości, a tym samym silnie wpływaja na podejmowane przez nas działania. Sa elementem porzadku symbolicznego obowiązującego w danym społeczeństwie. Po drugie - wyobrażenia geopolityczne dostarczaja swoistej dla danej grupy społecznej mapy świata, będac sposobem, w jaki wpływowe grupy społeczne definiują państwo, naród i świat (a tym samym stanowia jeden $z$ elementów samoidentyfikacji kulturowo-politycznej). Ludzie w swoich działaniach opierają się raczej na emocjach niż na rozsądku (racjonalnej kalkulacji), skąd wynika skłonność do nadawania modelom myślowym i wypływającym $z$ nich regułom wewnętrznej wartości. Dlatego też $z$ określonym terytorium, do którego rości sobie prawa dana grupa, wiąża się emocjonalnie nacechowane wyobrażenia i przedstawienia. Sa to wyobrażenia, dzięki którym członkowie danego państwa i zbiorowości kształtuja swoja wiedzę o własnej roli i miejscu w przestrzeni globalnej. Dzięki znajomości tych wyobrażeń można zrozumieć sposoby identyfikacji narodowej, a przede wszystkim znaczenie, jakie członkowie danej społeczności nadają takim pojęciom jak „tu” - „tam”, „my” - „oni”. W tym rozumieniu wszelkie „wizje geopolityczne” sa produktem odróżniającej tożsamości narodowej, która, definiując wymiar „my - oni”, jest źródłem silnych emocji i podłożem konfliktów międzygrupowych. Po trzecie - rozmaite idee i wyobrażenia generują określone formy mobilizacji społecznej. Istnienie swoistej dla danej grupy „mapy świata”, stanowiąc element wiedzy o otaczającym nas świecie, silnie wpływa na podejmowane przez nas działania, w tym także na działania o charakterze politycznym. Dlatego też dominujace w danym społeczeństwie wyobrażenia dotyczace otaczającej przestrzeni określa się niekiedy mianem „wyobrażeń geopolitycznych”, aby podkreślić ich znaczenie dla ukierunkowywania działań o charakterze politycznym. 
Reasumując, należy stwierdzić, iż wyobrażenia geopolityczne można zdefiniować jako zespół idei odnoszących się do relacji między czyjąś przestrzenia (miejscem) a pozostałym światem. Sa to geograficzno-polityczne założenia dotyczace miejsca i roli danego państwa w świecie, jego interesów, zagrożeń dla tych interesów, możliwych reakcji na te zagrożenia oraz sposobów legitymizacji swoich działań. Jest to sposób, w jaki dany kraj/zbiorowość sytuuje się wobec świata zewnętrznego. zespół wyobrażeń przestrzennych zwiazanych $z$ dana grupa oraz wyznaczajacych w dużym stopniu ich tożsamość i miejsce w świecie. Znaczenie tego terminu jest szerokie i elastyczne. W literaturze przedmiotu pisze się o „wyobrażeniach geopolitycznych”, „wizjach geopolitycznych” czy też „kodach geopolitycznych". Wszystkie te terminy można rozumieć jako wszelkie idee odnoszące się do relacji między „własnymi” a pozostałymi („obcymi”) przestrzeniami i miejscami, związane z poczuciem bezpieczeństwa/zagrożenia. Jest to wiedza porządkująca przestrzeń, w której działamy, dostarczająca nam pojęć służących do opisu otoczenia oraz swoistej „mapy świata”. Wyobrażenia geopolityczne sa zatem elementem porządku symbolicznego istniejącego $\mathrm{w}$ danym społeczeństwie. Kształtuja się pod wpływem różnorodnych czynników, takich jak bliższa i dalsza tradycja historyczna, edukacja, literatura, sztuka, reklama, kino, środki masowego przekazu, które przekazują i rozprzestrzeniają wśród członków danej grupy stereotypy i wyobrażenia o narodowej historii oraz przestrzeni zamieszkiwanej przez daną społeczność. Przedstawienia te upowszechniają się w ramach geopolitycznego dyskursu, obecnie inicjowanego i podtrzymywanego przede wszystkim za pośrednictwem mediów masowych, które bardzo często działają $\mathrm{w}$ interesach elit społeczno-politycznych. Jest to w dużym stopniu wiedza wytworzona społecznie przez określoną zbiorowość w specyficznych warunkach danego momentu historycznego, ukazująca niepokoje, pragnienia i interesy, które umotywowały takie jej określenie. 
Analiza wyobrażeń geopolitycznych przynosi wiedzę o postawach wobec świata, stwarzając badaczom możliwość identyfikowania motywów, którymi kierują się aktorzy polityczni w swoich działaniach. Każda grupa tworzy wiele różnorodnych wyobrażeń i przedstawień o swoim miejscu w świecie. Im zbiorowość jest większa i bardziej złożona, tym w jej ramach może funkcjonować wiele wyobrażeń, które moga być wykorzystywane i wzmacniane, lub też osłabiane, w zależności od kontekstu i sytuacji. Utrwalone w kulturze danej grupy wyobrażenia geopolityczne strukturyzuja nasze sposoby myślenia o świecie oraz stanowia podstawę legitymizująca podejmowane działania polityczne. W działalności politycznej poszczególne wyobrażenia geopolityczne przekładają się na system założeń dotyczących polityki zagranicznej państwa.

\section{Zakończenie}

Yves Lacoste uważał, że aby zrozumieć konflikty zachodzace w przestrzeni (konflikty geopolityczne), konieczne jest poznanie ich przyczyn oraz zrozumienie idei głównych autorów konfliktów: przywódców państw, liderów ruchów regionalnych, autonomicznych lub niepodległościowych oddziałujących na opinię publiczna. Dlatego też należy zająć się wyodrębnianiem oraz systematyczną konfrontacja spostrzeżeń i przekonań, jakie każda grupa polityczna ma na temat przestrzeni. Przekonania te wywodza się nie tyle $z$ racjonalnego i obiektywnego szacowania interesów grupy, ile przede wszystkim z jej kultury i doświadczeń historycznych. Każda przestrzeń polityczna, geograficzna czy też społeczna jest kształtowana i przeobrażana przez ludzi; ogromne znaczenie maja tradycja i pamięć historyczna, ta ostatnia stanowi główne źródło "geopolitycznych” wyobrażeń o świecie. Wielu badaczy uznało, iż warto się zastanowić nad znaczeniem trwałych, stereotypowych sposobów myślenia „geopolitycznego" czy też - inaczej to ujmujac - trwałych, stereotypowych sposobów postrzegania świata oraz swojego miejsca i roli 
w nim. Polityka państw zawsze opierała się, przynajmniej częściowo, na jakichś ogólnych wizjach i założeniach teoretycznych pozwalających określić relacje ze wszystkim, co znajduje się na zewnątrz. Wyobrażenia o świecie pozwalaja na świadome uprawianie polityki zmierzającej ku konkretnemu celowi. Każdy, kto podejmuje się kreowania wizji szeroko zakrojonej polityki, a zwłaszcza polityki międzynarodowej, musi się pokusić o jakąś terytorializację swojej wizji, musi mieć pewną wyobraźnię geograficzna. Refleksja nad światem „wyobrażeń przestrzennych” pozwala na polepszenie jakości badań nad środowiskiem międzynarodowym oraz większe wyczulenie teorii pod katem „rozumienia”. Taka analiza pozwala bowiem w sposób niejednowymiarowy tłumaczyć zależności między strukturą społeczną a ustrojem politycznym, a także między warunkami geograficznymi a polityka państwa.

Ze względu na swą wartość heurystyczna kategoria „wyobrażeń geopolitycznych" zaczęła się cieszyć dużą popularnością wśród geografów i politologów oraz zaczęło się pojawiać coraz więcej prac poświęconych tej problematyce. Niestety, polscy badacze rzadko podejmuja próby analizy „wyobrażeń geopolitycznych”. Duża część badaczy unika tematyki „geopolitycznej” ze względu na obawy związane $z$ posądzeniem o pseudonaukowość. Część traktuje geopolitykę jako dodatek do studiów nad środowiskiem międzynarodowym. To sprawia, że jakość analiz związanych z obecnościa „wyobrażeń geopolitycznych" w polskiej myśli społeczno-politycznej jest bardzo niska. Najczęściej „wyobrażenia”, które powstawały w określonym kontekście historycznym sa absolutyzowane, nadaje się im charakter „koncepcji strategicznych”, które kształtuja politykę danego podmiotu. Wyjątkiem sa próby analizy kontekstu społeczno-politycznego, w jakim kształtowały się na przykład polskie wyobrażenia geopolityczne i ogólnie traktowanie ich jako „wyobrażeñ”, a nie „prawd naukowych”. Wynika to przede wszystkim $z$ nieporozumień, które narosły w polskim środowisku akademickim wokół geopolityki jako specyficznego obszaru badań. Uporządkowanie wiedzy dotyczącej geopolityki, geopolityki krytycznej, a także „wyobrażeń geo- 
politycznych" powinno pozwolić na racjonalną dyskusję na temat wartości poznawczej tego typu badań.

\section{Bibliografia}

Bauman Z., Płynna nowoczesność, Wydawnictwo Literackie, Kraków 2006.

Blacksell M., Geografia polityczna, tłum. J. Halbersztat, Wydawnictwo Naukowe PWN, Warszawa 2008.

Dictionnaire de géopolitique, red. Y. Lacoste, Flammarion, Paris 1993.

Dijkink G., National Identity and Geopolitical Visions. Maps of Pride and Pain, Routledge, London 1996.

Gieseking J.J., Geographical Imagination, w: International Encyclopedia of Geography. People, the Earth, Environment, and Technology, red. D. Richardson i in., Wiley - Blackwell, New York 2017.

Gottmann J., The Significance of Territory, University of Virginia Press, Charlottesville 1973.

Gregory D., Geographical Imagination, Blackwell, Cambridge (Mass.) 1994.

Harvey D., Between Space and Time. Reflections on the Geographical Imagination, "Annals of the Association of American Geographers" 1990, t. 80, nr 3.

Harvey D., The Sociological and Geographical Imaginations, „International Journal of Politics, Culture and Society" 2005, t. 18.

Hepple L.W., Geopolitiques de Gauche. Yves Lacoste, Hérodote and French Radical Geopolitics, w: Geopolitical Traditions. A Century of Geopolitical Thought, red. K. Dodds, D. Atkinson, London 2000.

Lacoste Y., Attention: geographie!, „Hérodote” 1976, nr 1.

Lacoste Y., Editorial, „Hérodote” 1976, nr 1.

Lacoste Y., Geopolityka Śródziemnomorza, Wydawnictwo Akademickie Dialog, Warszawa 2010.

Lacoste Y., Une monde qui n'est pas futile, w: Le monde: espaces et systèmes, red. V.F. Durand, J. Levy, D. Retaile, Presses de Science Po, Dalloz, Paris 1993.

Lefebvre H., The Production of Space, Blackwell, Oxford 1991. Lorot P., Historie da la géopolitique, Economica, Paris 1995. 
Massey D., Space, Place and Gender, Minnesota University Press, Minneapolis 1994.

Neuman D., Citizenship, Identity and Location. The Changing Discourse of Israeli Geopolitics, w: Geopolitical Traditions. A Century of Geopolitical Thought, red. K. Dodds, D. Atkinson, Routledge, London 2000.

Schmid Ch., Henri Lefebure's Theory of the Production of Space. Towards a Three-Dimensional Dialectic, w: Space, Difference, Everyday Life. Reading Henri Lefebure, red. K. Goonewardena i in., Routledge, London - New York 2008.

[O']Tuathail G., Geopolitical Structures and Cultures. Towards Conceptual Clarity in the Critical Study of Geopolitics, w: Geopolitics. Global Problems and Regional Concerns, red. L. Tchantouridze, University of Manitoba, Winnipeg 2004, s. 84.

Замятин Д.Н., Власть пространства и пространство власти, РОССПЭН, Москва 2004.

\section{"Geopolitical Imaginations" as a Research Subject in Contemporary Political Geography}

The theories of Henri Lefebvre on the Production of Space have influenced our understanding of the ontology of space. The processes of constructing and "appropriating" space are important elements of man's political activity. Space is not neutral; its alleged objectivity is treated in a voluntary manner, depending on political demand. The importance given to geographical space and the supposed "laws" governing history are instruments of political indoctrination or propaganda justification of the pursued policy pursued. Space is political and ideological. Borders, political maps and states are the products of human political activity; they are "socially produced". In contemporary political geography, the theme of "the production of space" is very popular. The main goal of the article is to analyse the currently important research category - "geographical imaginations". This category is mainly used to understand our perception of space and the roots of political conflicts.

Keywords: critical geography, geopolitical images, social production of space. 